\title{
The Federal Election of 2002
}

\author{
Robert Rohrschneider
}

Political Science, Indiana University

Michael R. Wolf

Political Science, Indiana University - Purdue University Fort Wayne

\section{The Federal Election, Context 2002}

During the summer of campaign year 2002, the election already seemed lost for the SPD/Green government. Public opinion polls saw the governing coalition trailing by several percentage points, whereas the $\mathrm{CDU} / \mathrm{CSU}$, together with the FDP, looked like the sure winner. A central reason for the malaise of the red-green government was the ailing economy. Unemployment rates hovered at the 4 million mark and would have been even higher if governmentfunded jobs had been added to the official unemployment rates. Consequently, a substantial majority of citizens considered the creation of jobs Germany's most important problem. ${ }^{1}$ This constituted an especially severe burden for Chancellor Schröder. In 1998 he had promised to push unemployment rates below 3.5 million or, he stated, he did not deserve re-election. Thus, many observers and voters expected the September 2002 election to be a referendum on the governments' handling of the economy. Since the chancellor had not delivered, voters were about to vote the incumbent government out of office.

We now know that the consensus among pundits and citizens did not come true because the SPD emerged as the strongest party, albeit by a margin of less than 9,000 votes (see Table 1 ). The redgreen government fared especially well in the east, due in large part to the strong showing of the SPD, which gained 4.6 percent compared to 1998. In contrast, the SPD lost 4 percent among western voters. The Union's share increased overall by 3.4 percent, of which 
the CSU in Bavaria alone contributed 2.3 percent. The CDU's 1.1 percent overall gain in 2002 was modest, especially when one considers that the Union had one of its worst election results in 1998.

Table 1 Federal and regional election results, 2002 and 1998

\begin{tabular}{lrrrrrr} 
Party & \multicolumn{2}{c}{ Percent Federal } & \multicolumn{2}{c}{ Percent West } & \multicolumn{2}{c}{ Percent East } \\
& 2002 & 1998 & 2002 & 1998 & 2002 & 1998 \\
SPD & 38.5 & 40.9 & 38.3 & 42.3 & 39.7 & 35.1 \\
CDU & 29.5 & 28.4 & 29.8 & 28.7 & 28.3 & 27.3 \\
CSU & 9.0 & 6.7 & 11.0 & 8.4 & $*$ & $*$ \\
Greens & 8.6 & 6.7 & 9.4 & 7.3 & 4.7 & 4.1 \\
FDP & 7.4 & 6.2 & 7.6 & 7.0 & 6.4 & 3.3 \\
PDS & 4.0 & 5.1 & 1.1 & 1.2 & 16.9 & 21.6
\end{tabular}

Note: Data from Federal Returning Officer, Statistisches Bundesamt.

Among the smaller parties, the very strong showing of the Greens is remarkable. It increased its vote share by nearly 2 percent, no doubt in part because of the popularity of Joschka Fischer. In addition, issues like the flood (environmentalism) and the Iraq crisis (peace movement) enhanced the salience of issues the Greens squarely address. In contrast, the PDS failed to reach the 5 percent mark. Consequently, it is represented by only the winners of two Berlin districts. The FDP managed to increase its vote share by 1.2 percent. This could have been a success had it not set a widely ridiculed goal of 18 percent during the campaign.

Pundits and the mass media alike were quick to advance reasons for the unexpected result. Did the incumbent parties carry the day because of the flood, or did the Iraq issue sway voters in the last few days? Was it the popularity of the chancellor? Did the Union not make enough of the persistent economic problems during its campaign? To what extent could the red-green government base the campaign on its policy achievements during the first legislative period? And what, if any, consequences did the various intraparty problemsthe finance scandals in particular-have for the election outcome?

We assembled a team of experts on German electoral politics and policies to address these and related questions. We are interested in the processes that generated the election results in 2002, but also the implications of these findings for the long-term evolution of the German party system. Before they present their views, however, this 
chapter previews the most important developments during the 1998-2002 legislative period, paying particular attention to the 2002 election campaign.

\section{8-2001: Accomplishments and Failures of Government and Opposition}

When the red-green government started its work in 1998, it faced many questions following its victory over the CDU/CSU - FDP government. As junior partner, for instance, how much would the Greens be forced to practice pragmatic politics despite the party's "antiparty" roots? For the pragmatist Gerhard Schröder, how does one satisfy the "new middle" he targeted in 1998, yet also gratify the socialist wing of his party and the labor unions?

The centrist economic approach taken by Schröder marked one of many significant shifts away from the SPD's roots. The Schröder government helped forge corporate-labor agreements that left unions complaining that pay would not match inflation. The government also pushed for pension reforms that included partial-privatization. Budget cuts, plus corporate capital gains reductions and individual tax cut reforms also did not follow norms of continental social democracy. Indeed, the SPD's economic minister (and Schröder's political rival), Oskar Lafontaine, resigned because he felt such fiscal policies came at the expense of the party's socialist roots. The irony was that Lafontaine's resignation boosted the deutsche Mark and markets responded positively to his departure. This highlighted that Schröder's middle-of-the-road economic policies were more welcomed in corporate board rooms than union offices.

None of Schröder's fiscal policies were able to budge the sluggish German economy, however. Marginal economic growth appeared, but by mid-2001 the economy ceased growing and the number of unemployed eventually would surge back over 4 million. No matter how often the chancellor reasoned that there was "no cause for panic," he failed to live up to his key election promise. Thus, bargaining the historical ideology of his party had not paid off in any measurable way. Schröder entered the campaign year 2002 with critics 
from within his party as well as opponents waiting to pounce on his unemployment pledge (see Rohrschneider and Fuchs, this volume).

In foreign affairs, the coalition appeared to find its voice. ${ }^{2}$ Despite being chastised by the European Union for not meeting particular economic requirements, the government seemed to be forging a more significant footing for Germany within Europe. Foreign Minister and Green party leader Joschka Fischer first suggested a more federalized European Union, a theme that was echoed and expanded upon by Chancellor Schröder in a significant 2001 speech. The Fundi wing of the Greens, which has long opposed NATO, watched as the Realo Green members of the Bundestag agreed with their party leader to provide significant numbers of troops to NATO missions. In unprecedented moves, the government provided troops to missions in Kosovo, Macedonia, and Afghanistan.

This is not to suggest that the Greens ceded their policy base. The party won several key victories. Despite some heel-dragging by the SPD in response to energy industry pressure, the government established a phase-out of all nuclear energy plants. ${ }^{3}$ This had been a key concession to get the Greens to join the coalition in 1998. The government also implemented the Green-championed "ecology tax", which incrementally raised taxes on gas. Another postmaterialist and controversial policy victory for the Greens was the legalization of gay marriages. Additionally, the government addressed the thorny immigration issue and passed legislation that liberalized citizenship and naturalization laws.

Despite these accomplishments, particular ministers embarrassed the government and added to the pain resulting from the persistent economic malaise. ${ }^{4}$ While each of these incidents damaged the SPDled government, the CDU faced a much greater challenge from scandal. By late 1999, the CDU had crept ahead of the SPD in popularity, won numerous state level elections, and out-performed the SPD in European Parliamentary elections. Figure 1 displays the Politbarometer survey responses to the question of which party a respondent would support if the election were held next Sunday. ${ }^{5}$ The CDU's gains fit the "normal" cycle of the opposition faring well between elections. However, the Christian Democrats then faced their largest internal crisis ever, just as they were recovering from their 1998 defeat. 
In late November 1999, former Chancellor Kohl admitted to accepting political donations to the CDU that illegally were kept off the books. Accusations that this money bought influence could not be countered because Kohl refused to supply the names of donors. Investigators accused him of destroying documents, and the resulting furor tarnished Kohl's reputation along with the party's standing. The investigation turned up embarrassing, if unrelated, evidence on other key party leaders such as Wolfgang Schäuble. ${ }^{6}$

Figure 1 German Sunday question, 1998-2002

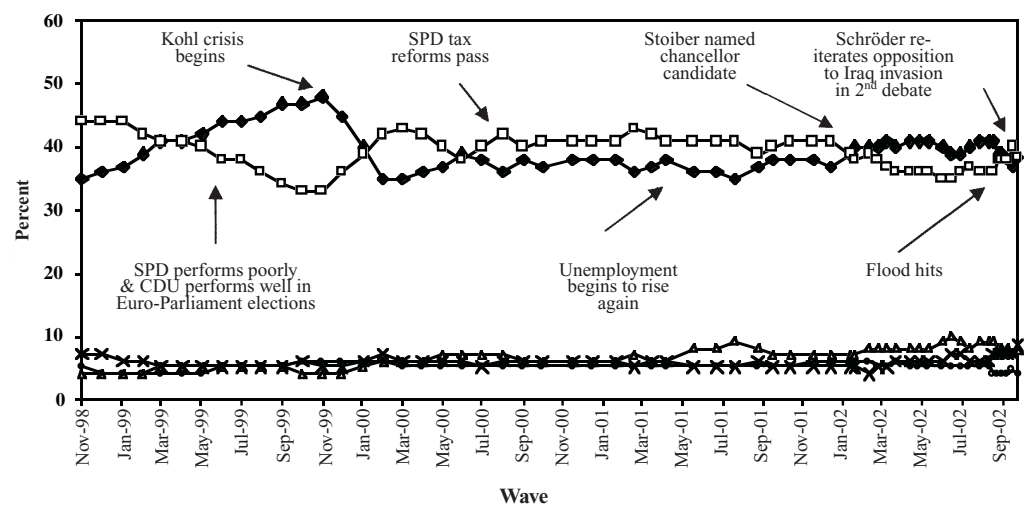

$\multimap$ CDU/CSU $\rightarrow$-SPD $\rightarrow$ FDP $\rightarrow$ Greens $\multimap$ PDS

With the resignation of both Kohl and Schäuble, the Christian Democrats were left without experienced leadership. Further, it squandered the positive ground the party had made up since the 1998 election. Instead of a four-year stretch of popular opposition for the Union that could set the stage for a successful defeat of the government, the SPD actually made gains. Indeed, legislative successes such as the tax cut package actually bolstered the SPD vis-àvis the Union until 2002, even though unemployment had begun to rise again and the economy faltered.

To shore up the Union, the CDU elected Angela Merkel as their leader in January 2002. She provided a refreshing face to a party who had seen its leadership removed by scandal. Her youth and eastern roots were benefits, but they could not always overcome her 
inability to rally the party. Party leaders were not confident that she provided a legitimate foil to the chancellor, and she was unable to paper-over key policy differences with the CSU. Edmund Stoiber, leader of the CSU, was seen as a stronger leader but often was painted by opponents as extreme. This left the Union with one leader who held more popular positions on issues but was seen to lack leadership, while the stronger leader often held positions seemingly out-of-step with many Germans.

Before 2002, the FDP had redesigned the government's proposed changes to immigration policy. It should have provided a means for the liberals to recapture some of the ground they lost in their dismal 1998 electoral performance. They faced a dilemma, however. Many analysts praised their firm policies on key economic recovery issues, but they were caught in the middle of pursuing both major parties as a potential coalition partner. ${ }^{7}$ Unaccustomed to being out of power, the FDP had to actively pursue the role of kingmaker rather than having the luxury of being wooed by either major party.

The PDS retained its distinctly regional image. Despite attempts to broaden its appeal among western voters, it clearly remained mainly a representative of eastern voters. While the popular party leader Gregor Gysi was an often-seen guest in western television, his affability and popularity did not broaden the appeal of the PDS party to western voters.

None of the parties necessarily had a good four years. The government was left particularly vulnerable due to a poor economy; the Union, in the wake of the finance scandal struggled to formulate clear, plausible, and feasible alternatives to government policies; and the minor parties remained in the shadows.

\section{The Campaign Year}

Entering the campaign year, economic conditions dominated the electoral landscape. The German economy and the deutsche Mark had always been seen as important engines for the European Union economy and the Euro. In 2002, however, the European Commission scolded Germany for getting too close to the 3 percent deficit cap as part of the stability pact for the Euro. Further, a general right- 
ward ideological shift was occurring throughout Europe, which culminated in the electoral loss for the Socialists in France. Part of this movement was a response to September 11 and a reaction to fears, real or imagined, about immigration.

The red-green government had reason to fear that immigration liberalization might produce a backlash. Schill's Party for a Law and Order Offensive had done very well in local Hamburg elections in late September 2001 by tapping into the embarrassment generated because some of the September 11th hijackers had lived in Hamburg.

In this setting, each party staked out particular programmatic appeals. Under Guido Westerwelle, the FDP took aggressive neoliberal economic stances and called for tighter immigration laws. In an attempt to expand their appeal, Greens highlighted economic issues such as their support for the government's tax cuts and the need for labor reform, while also discussing social issues such as education. They even changed their party manifesto for the first time since 1980 and included positive references to military action under particular conditions. The PDS tried to attract westerners by highlighting issues other than eastern economic problems such as their pacifist stance on military action or involvement in peacekeeping efforts.

With both Merkel and Stoiber staking their claim to the candidacy, the CDU and CSU entered the year with a difficult choice to make between possible chancellor candidates. In January Merkel stepped aside, leaving the rare occurrence of the smaller and more conservative CSU in charge of winning the election. Getting both Union parties together has not always been easy, however. As campaign manager in 1980, Edmund Stoiber had learned the tough lessons from Franz-Josef Strauss' campaign. He consequently moved to merge the Christian Democrats' issue concerns with his own more conservative Christian Socialist positions. Stoiber also realized that he needed to work with the CDU rather than usurp power to Bavaria. The parties released a common manifesto and members of Stoiber's "competence team" of would-be ministers included such CDU figures as former-leader Wolfgang Schäuble. As a result, the Union centered their campaign on decreasing marginal tax rates as well as decreasing the overall public share of the economy. Their campaign hammered the SPD's economic performance and called 
for increased privatization and a halt to the implementation of the "ecology tax."

Numerous scandals affected the parties and provided distractions from issue debates during the election year, including the Federal Labor Office in the winter admitting that it over-counted the number of people findings jobs in a period of high unemployment. In the spring, Jürgen Möllemann, an FDP leader, created controversy by claiming that Israel pursued Nazi-like policies. In July, soon-tobe-deposed Defense Minister Scharping could not square whether Germany could fulfill military airplane orders and faced accusations of a financial relationship with a lobbyist. Later that same month, the misuse of frequent flyer miles for personal use implicated many politicians and led to the resignation of PDS leader Gregor Gysi. Finally, days before the election an SPD minister accused the Bush administration of using foreign policy to distract away from domestic problems as the Nazis had. Generally these scandals increased the public malaise about politics and distracted press coverage from policy issues.

To an unprecedented degree, the parties concentrated on the personal characteristics of their leaders. For the FDP and Westerwelle, the SPD and Schröder, and Fischer and the Greens, this was due to their energetic and dynamic leaders. For the CDU/CSU and Stoiber, this was due to his competence. Stoiber, whose low-unemployment and high-tech Bavaria provided an excellent comparison to Schröder, gave the Union a boost in the polls. It became easy for Germans to compare the economic success - the laptops and lederhosen - in Bavaria to the economic difficulties elsewhere. As Figure 1 illustrates, the point at which the Union begins to recover from the Kohl fiasco to draw even and then pass the SPD on the party preference question came after January 2002 when the Union chose Stoiber. The two major parties even agreed to have two US presidential election-style debates between the chancellor candidates. Instead of focusing attention on the arguments penned in the parties' manifestoes, the campaign emphasized the issues, arguments, and performance of the candidates in the debates. So concentrated on the individual leaders was the focus of the campaign that the Greens highlighted a single candidate for the first time. Fischer was even outfitted with a luxury tour bus for nonstop campaigning throughout Germany. 
The press obliged the parties' candidate-centered campaigns, and, because of the popularity of Schröder and Fischer, this greatly benefited the SPD/Green coalition. ${ }^{8}$ When asked to compare the chancellor candidates on characteristics and on particular issues, respondents rated Schröder's personal image higher than Stoiber's, even though they generally thought that Stoiber would better handle economic and employment issues. As displayed in Figure 2, the public preferred Schröder as chancellor over Stoiber throughout 2002. What is particularly noteworthy, however, is the trend during August and September. Here, Schröder's lead grows significantly and quickly. This is also the period that catapulted the SPD in front of the CDU/CSU in the party preference trend in Figure 1.

Figure 2 "Whom would you prefer as chancellor?"

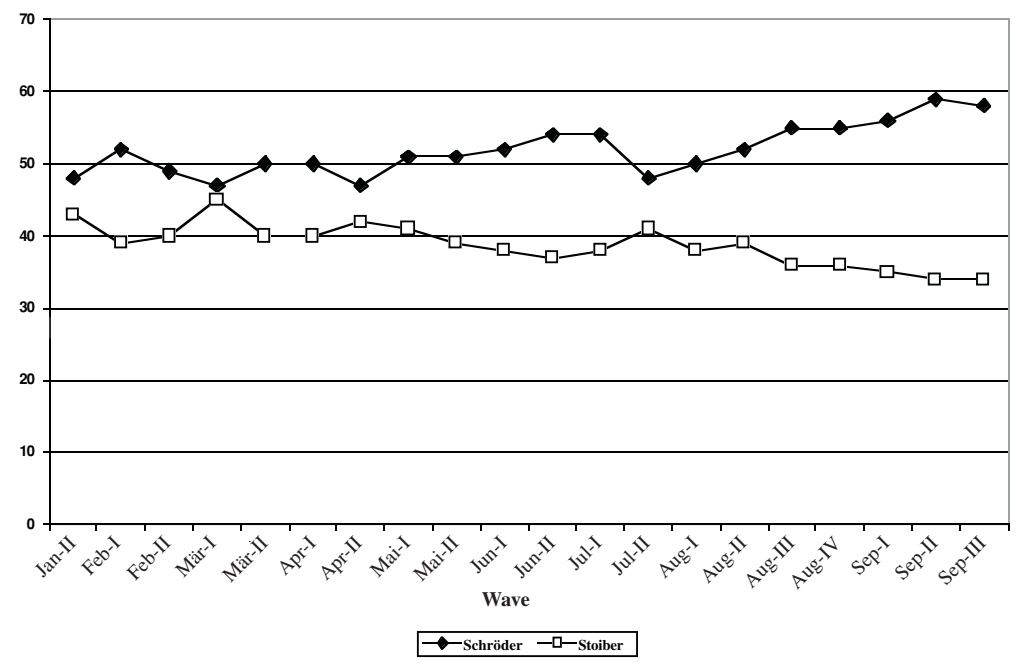

Finally, experts placed the number of voters who entered the campaign as undecided at about 30 percent of the public. ${ }^{9}$ This meant that the CDU/CSU lead over the SPD was soft, since about onethird of the electorate lacked a firm vote commitment. Consequently, despite all of the negative factors facing the SPD and the Greens, the election would be decided during the campaign; short-term influences would rival long-term economic and partisan influences. 
Two issues have been routinely cited as key to the election outcome. First, when the largest flood in 500 years hit eastern Länder in mid-August, Schröder promised assistance without red-tape and delayed the following year's tax cuts. He emerged as a statesman during a period of national purpose. The chancellor and other officials quickly appeared at flood sites, and later Schröder took a leadership role at emergency flood-related European Commission meetings. Stoiber, on the other hand, could not match the chancellor's official role or personal skill in this crisis.

Second, in early August Schröder stated that Germany would not participate in any military action against Iraq, regardless of what the United Nations decided on the issue. This unilateral statement of German independence catered to the antimilitary views of traditional SPD supporters, and formerly PDS voters in the east. The general public was also unenthused about a possible war, especially when other key peacekeeping missions had begun to involve German military troops. This, along with stating that Germany would not "click its heels" in response to US wishes drove the story further as the Bush administration began to protest (see Rohrschneider and Fuchs in this volume).

The issue came to a head in the second debate between the chancellor candidates. Stoiber responded that he did not support unilateral US action but did not want to narrow any options against Iraq. Schröder's firmer stance prevailed. In lieu of any positive economic data and the consistent and effective criticism on the part of the Union against SPD economic policy, there can be no other explanation as to why the SPD bounced back into contention with the Union than the confluence of the stance against Washington on Iraq and Schröder's performance during the flood crisis. As Figure 1 shows with the vote preference question during the final two months of the campaign, the SPD's position improved vis-à-vis the Union and led to the tie in public opinion polls right before the election.

\section{Plan of the Volume}

This chapter's initial discussion of the dynamics of the 2002 Federal election only touches on the superficial dynamics of the vote. The 
specific aspects of this election must be tied into the more general trends of German party politics and German voting behavior. As each chapter shows, and as they together reveal, the 2002 federal election, while exciting and punctuated by unique events, did not depart drastically from long-term trends underway in the Federal Republic and in advanced industrial democracies generally. Scholars in the future will not point to the 2002 results as a watershed change from earlier German electoral periods. Granted, the personalization of the candidates' campaigns, the emergence of the Iraq and flood issues, and the numerous changes in party fortunes provided the election with a unique flavor. Nevertheless, the following chapters demonstrate that German voters still exemplify systematic voting behavior, albeit under the much more fluid conditions produced because of the yet unaligned eastern Länder and their increasingly dealigned western counterparts.

The volume begins with an essay by Helmut Norpoth and Thomas Gschwend who correctly predicted the proportion of nationwide votes for the red-green coalition several months before the election. Their predictive success is remarkable given that most pundits at that time had viewed as slim the government's chances to win the election. The essay also suggests that the two main influences on voting behavior remain long-standing party loyalties and the shorterterm popularity of candidates-a theme that pervades this volume.

Dieter Roth's chapter then discusses several central themes that emerged during the 1998-2002 period and explains how citizens viewed the campaign. He pays particular attention to the influence of sociostructural factors on vote choice-and documents that the 2002 election further accentuates the development towards a more volatile, centrist, non-partisan electorate.

Russell J. Dalton and Wilhelm Bürklin provide evidence and reasons for fluidity among German voters. Their analyses suggest that the social cleavages that structured partisanship and political behavior have eroded over time. This produces considerable volatility in voters' party support, as evidenced in a growing tendency toward vote switching, split-ticket voting, and the late timing of voting decisions. Further, the numerous shifts of party fortunes during the 2002 election were but an example of increased numbers of permanent "Wechselwähler" in the German public. 
Robert Rohrschneider and Dieter Fuchs show that independents viewed a CDU/CSU-led government as more competent to address economic problems than a SPD-led government. Their analyses also show, however, that this lead was quite soft. Moreover, they argue that the SPD/Greens benefited significantly from their Iraq stance as well as how they handled the flood in the east. The chapter shows that both issues offset the slight advantage the Union held in the economic domain.

The contribution by Christopher J. Anderson and Frank Brettschneider discusses the important role of candidate images on the vote. The conventional wisdom has suggested that 2002 was an American-style election where Schröder's personal characteristics trumped Stoiber's bland, if competent, persona. In contrast to other chapters in this volume, the authors question this conclusion because they see no evidence that the personalities of the chancellor candidates are more important than substantive political explanations.

Susan E. Scarrow's essay traces the finance scandals that plagued most parties during the legislative period, particularly the major parties. She argues that one important consequence for this election was that two important personalities did not lead their parties: Schäuble in the Union, and Gysi for the PDS. It is intriguing to speculate whether the PDS would have managed to pass the five percent threshold, or whether the Union would have appealed to more voters outside the southern states if they had been their parties' standard bearers.

Two chapters trace the policy context of the election campaign and the implications for the new government. Werner Reutter's essay shows that the red-green government was quite successful in several economic areas, especially during the first half of the legislative period. He also provides evidence that the government cannot blame the federal structure for its failures to deliver policies in some arenas.

William M. Chandler's analysis focuses on two central foreign policy issues. He first traces how the Iraq issue became injected into the campaign and speculates how this may have affected the election results. He also raises the intriguing question of why another important foreign policy issue-that of the European integration-never attracted the attention of the Iraq controversy, despite the fact that integration is eminently important for Germany. 
It is a pleasure to thank a number of institutions that contributed to the success of this volume. First, we would like to thank the German Academic Exchange Service (DAAD), Dieter Dettke and the Friedrich-Ebert Foundation, the Institute on Global Conflict and Cooperation at UC San Diego, and the Center for the Study of Democracy at UC Irvine for their support in underwriting a conference at Laguna Beach in January of 2003. We also appreciate the support of Samuel Barnes and the BMW Center for German and European Studies at Georgetown University. A special acknowledgement is due to Andy Markovits for his enthusiastic support of developing this conference into a special issue of the journal. It is our great pleasure to contribute this collection to Andy's penultimate issue as editor of German Politics and Society and to acknowledge his enduring commitment to the study of German elections and parties, and German politics more broadly.

The quality of the papers benefited greatly from our ability to present and discuss the papers before the final drafts were prepared. Special thanks are due to the discussants at the conference: Samuel Barnes, Shaun Bowler, Alexandra Cole, Dieter Dettke, John Leslie, and Peter Merkl. Second, we would like to thank Peter RuhenstrohBauer and the Bundespresseamt of the Federal Republic, which invited several contributors to this volume to an information tour during the 2002 election campaign. Nearly all of the themes covered in this volume were first developed and discussed during the trip to Germany. Finally, we are grateful to Dieter Roth and the Forschungsgruppe Wahlen, which provided the contributors to this volume with a wealth of public opinion data covering the election campaign (the Politbarometer surveys).

\section{Notes}

1. The Forschungsgruppe Wahlen, for example, consistently reported that at least 70 percent of voters viewed unemployment as the most important problem in Germany during the 2002 election year. 
2. See William Chandler's contribution to this volume.

3. See Werner Reutter's contribution to this volume.

4. The popular Foreign Minister Joschka Fischer had to refute stories linking him with Red Army Faction figures in his past. Further, besides Lafontaine, the SPD had other noteworthy resignations, including a foreign policy advisor who had leaked notes on security meetings with the United States as well as having thrown a very public temper tantrum while abroad, and a transport minister who had been linked with an embezzlement scheme in his previous position. No other scandals embarrassed the government as much as the accusations that Defense Minister Rudolf Scharping used defense aircraft to shuttle him to see his high-society girlfriend. While the accusations were denied, the story was one of many that damaged Scharping's standing and led to his eventual sacking.

5. We use the weighted version of the Forschungsgruppe Sonntagsfrage.

6. See Susan E. Scarrow's contribution in this volume.

7. See Dieter Roth's contribution in this volume.

8. For a contrasting view, see the article by Christopher J. Anderson and Frank Brettschneider in this issue.

9. See Russell J. Dalton and Wilhelm Bürklin in this volume. 